\title{
MEASUREMENT OF FETAL OCCIPUT-SPINE ANGLE DURING THE FIRST STAGE OF LABOR IN PRIMIGRAVIDA AS A PREDICTOR OF THE MODE OF LABOR
}

\author{
By
Nour Gamal Abd El-Nasser, Ismael Mohamed Abd El-Azem Mira and Abd El-Monsef Abd El-Hamed Sedek \\ Department of Obstetrics\& Gynecology, Faculty of Medicine, Al-Azhar University \\ Corresponding author: Nour Gamal Abd El-Nasser, \\ E-mail: nourabdelnasser90@gmail.com
}

\begin{abstract}
Background: Fetal head "attitude" (relationship of fetal head to spine) in the first stage of labor may have a substantial impact on labor outcome. The diagnosis of fetal head deflexion traditionally is based on digital examination in labor.

Objectives: To quantify the degree of fetal head deflection via the use of Ultrasound during the first stage of labor, and the relationship with the course and outcome of labor.

Patients and methods: This was a prospective study conducted at Sayed Galal Hospital, Al-Azhar University from June 2019 to December 2019. Nonconsecutive series of women with uncomplicated singleton pregnancies at term gestation (37 weeks or more) were submitted to trans-abdominal ultrasound during the first stage of labor. Fetal position was occipito-anterior, and the angle between the fetal occiput and the cervical spine (the occiput-spine angle) was sonographically obtained on the sagittal plane. The measurements of the occipito-spine-angle were performed offline by an operator who was blinded to the labor outcome. The intra- and inter observer reproducibility and the correlation between the occipito-spine angle and the mode of delivery were evaluated.
\end{abstract}

Results: A total of 400 pregnant women were recruited, 350 of which underwent a spontaneous vaginal delivery, and 50 were submitted to cesarean delivery. The mean value of the occipito-spine angle measured in the active phase of the first stage was $126^{\circ} \pm 2.79^{\circ}$ (SD). The occipito-spine angle was significantly narrower in women who underwent CS delivery due to labor arrest. A larger occipito-spine angle (i.e. $>126^{\circ}$ ) showed to be significantly associated with a shorter duration of labor.

Conclusion: Fetuses with smaller occipito-spine angle $\left(<126^{\circ}\right)$ were at increased risk for operative delivery.

Keywords: Fetal Occipito-Spine Angle, First Stage of Labor Primigravida, Ultrasound.

\section{INTRODUCTION}

Worldwide, cesarean section is the most common major procedure done by surgeons (Madsen et al., 2013). Spontaneous vaginal birth without intervention is the ideal route for most pregnancies. Failure of progression in

some women may need some
interventions including cesarean or
instrumental delivery (Towner et al.,
2010).

In the vertex presentation, the vertex is flexed such that the chin rests on the fetal chest, allowing the suboccipito-bregmatic 
diameter of approximately $9.5 \mathrm{~cm}$ to be the widest diameter through the maternal pelvis. This is the smallest of the diameters to negotiate the maternal pelvis (Laughon et al., 2012).

The arrest of labor progression is the leading cause of obstetric interventions, including cesarean delivery and instrumental vaginal delivery (ACOG, 2012).

Deflexed head can cause arrest of labor and accounts for $1 / 3$ of cesarean sections performed for that arrest (Laughon et al., 2012).

Three varieties of deflexed cephalic mal-presentations traditionally are described according to the degree of head extension, including sinciput, brow, and face (Kish and Joseph, 2013).

Failed labor cannot be explained by fetal size only as most cases that experience disproportion have normal range of fetal birth weights. Thus, other factors as head mal-positions and malpresentations may cause obstruction. These include asynclitism, occiput posterior position, and face and brow presentations (Cunningham et al., 2014).

Normally, late in pregnancy, a characteristic attitude is assumed by the fetus. It becomes folded upon itself so that it makes its back markedly convex with a sharply flexed head sharply making the chin in contact with the chest. Abnormalities to that attitude may occur. The fetal head may become progressively extended changing its position from the vertex to face. This results in changing of the vertebral column contour from convex to concave (Cunningham et al., 2014).
Apart from major degrees of head deflexion, there are minor degrees that cannot be detected clinically. The use of trans-abdominal ultrasound at the suprapubic area can detect theses minor degrees which may be responsible for abnormal progress of labor (Ghi et al., 2016).

The aim of this study was to quantify the degree of fetal head deflexion via the use of ultrasonography during the first stage of labor, and to determine whether a parameter derived from ultrasound examination (the occiput-spine angle) has a relationship with the course and outcome of labor.

\section{PATIENTS AND METHODS}

This was a prospective study conducted on total of 400 women with gestational age 37 weeks or more and in primigravida were assessed in this study at Sayed Galal Hospital, Al-Azhar University between June 2019 till December 2019 by 2 dimensional ultrasound. Examinations were performed after a verbal consent from every patient.

These patients were divided into 2 groups: Group I: 333 pregnant women with OSA 126 or more, and Group II: 67 pregnant women with OSA less than 126.

\section{Inclusion criteria:}

1. Age between 18 - 30 years old.

2. BMI was less than 30 .

3. The gestational age between 37- 42 weeks (calculated by LMP or 1 st trimesteric U/S).

4. Singleton pregnancy.

5. Primigravida.

6. Occipito-anterior position. 
7. Active phase of first stage of labor.

\section{Exclusion criteria:}

1. Age ( $<18$ years old or $>30$ years old).

2. Occipito-posterior position.

3. Indications of cesarean section like malpresentations, macrosomia, placenta previa, previous cesarean section.

4. Multiple gestations.

5. Medical disorders like hypertension, DM, liver or renal diseases.

\section{All patients selected for our study were subjected to the following:}

1. Verbal informed consent.

2. Full history taking (age, parity, LMP, medical and surgical history).

3. General examination including BMI, vital signs, abdominal and pelvic examination.

4. GE E6 Abdominal ultrasound with a probe of 2-5 $\mathrm{MHz}$ will be done during the first stage of labor.

5. Ultrasonographic examination was performed transabdominally with the patient in the supine position. The ultrasound transducer was first placed transversely in the suprapubic region of the maternal abdomen. The landmarks depicting fetal position were the fetal orbits for occipitoposterior position, the mid-line cerebral echo for occipito-transverse positions and cerebellum or occiput for occipito-anterior position. For the latter, the fetal spine was demonstrated in its sagittal plane and traced from the fetal thorax to the occiput.
6. The occiput-spine angle was measured three times through the latent and the active stage of labor. A sagittal plane showing both the fetal head and spine was obtained. Three images were taken by one investigator. The angle between two tangential lines to occipital bone and the vertebral body of the first cervical spine was measured three times and the mean was taken.

7. The sonographer was not involved in the patient's care, and the managing obstetrician was blinded to the ultrasound findings and the occiputspine angle. For each patient of the study group, the progress of labor using a partogram (cervical dilation, effacement, consistency, position and station) and the mode of delivery were assessed retrospectively.

8. Prolonged first stage of labor was defined as cervical dilation $<1.2 \mathrm{~cm} / \mathrm{h}$ in primigravida for 3 hours while arrest of the first stage was defined as non-progression of cervical dilation for $>4$ hours despite adequate uterine activity (3-5 contractions every 10 minutes).

9. Prolonged second stage of labor was defined as fetal head descent $<1 \mathrm{~cm} / \mathrm{h}$ in nullipara while arrest of the second stage was defined as lack of fetal head descent after two hour, or three hours with epidural analgesia in nullipara.

10. Neonatal assessment: Follow up the neonate for Apgar score at $5 \mathrm{~min}$.

\section{Statistical Analysis:}

All statistical calculations were done using computer program SPSS (Statistical Package for the Social Sciences; SPSS 
Inc., Chicago, IL, USA) release 22 for Microsoft Windows (2000). Data were statistically described in terms of frequencies (number of cases) and percentages. For comparing data, Chisquare (X2) test was performed. Accuracy was represented using the terms sensitivity, and specificity. Receiver operator characteristic (ROC) analysis was used to determine the optimum cut off value for the studied diagnostic markers. $p$ values less than 0.05 was considered statistically significant.

\section{RESULTS}

A total of 400 women participated in the study, whose age ranged between 1830 years old $90 \%$ of our cases were $\leq 25$ years old and $10 \%$ were over 25 years old. All patients were with history of vaginal delivery $(100 \%)$. Those patients were divided into 2 groups: Group I was: 333 pregnant women with OSA 126 or more, and Group II: 67 pregnant women with OSA less than 126.

The influence of OSA on progress of labor was compared between the 2 groups regarding the incidence of maternal, fetal complications and mode of delivery (Table 1).

Table (1): Demographic characteristics of pregnant women in this study

\begin{tabular}{|c|c|c|}
\hline \multicolumn{2}{|c|}{ Characteristics } & Percentage (\%) \\
\hline \multirow{2}{*}{ BMI } & $18-24.9 \mathrm{~kg} / \mathrm{m} 2$ & $30 \%$ \\
\cline { 2 - 3 } & $25-30 \mathrm{~kg} / \mathrm{m} 2$ & $70 \%$ \\
\hline \multirow{2}{*}{ Age } & $18-25$ years & $90 \%$ \\
\cline { 2 - 3 } & $>25-30$ years & $10 \%$ \\
\hline \multirow{2}{*}{ Parity } & Primigravida & $100 \%$ \\
\hline
\end{tabular}

There were statistically significant differences between OSA $<126$ and 126 or more according to labor progress, mode of delivery, and fetal complications (Table 2).

Table (2): Comparison between OSA $<126$ and 126 or more according to labor progress, mode of delivery and fetal complications

\begin{tabular}{|c|c|c|c|c|c|c|c|c|}
\hline \multirow{3}{*}{\multicolumn{2}{|c|}{$\mathrm{P}_{\text {Parameters }}$ Angle Group }} & & & \multirow{2}{*}{\multicolumn{2}{|c|}{126 or more }} & \multirow{2}{*}{\multicolumn{2}{|c|}{ Total }} & \multirow{2}{*}{$\mathbf{P}$} \\
\hline & & \multicolumn{2}{|c|}{$<126$} & & & & & \\
\hline & & No. & $\%$ & No. & $\%$ & No. & $\%$ & \multirow{3}{*}{$<0.001$} \\
\hline \multirow{2}{*}{$\begin{array}{c}\text { Labor } \\
\text { progress }\end{array}$} & Normal & 15 & $22.4 \%$ & 294 & $88.3 \%$ & 309 & $77.3 \%$ & \\
\hline & Abnormal & 52 & $77.6 \%$ & 39 & $11.7 \%$ & 91 & $22.8 \%$ & \\
\hline \multirow{2}{*}{$\begin{array}{l}\text { Mode of } \\
\text { delivery }\end{array}$} & CS & 31 & $46.3 \%$ & 19 & $5.7 \%$ & 50 & $12.5 \%$ & \multirow{2}{*}{$<0.001$} \\
\hline & VD & 36 & $53.7 \%$ & 314 & $94.3 \%$ & 350 & $87.5 \%$ & \\
\hline \multirow{3}{*}{$\begin{array}{c}\text { Fetal } \\
\text { Complications }\end{array}$} & No & 54 & $80.6 \%$ & 331 & $99.4 \%$ & 385 & $96.3 \%$ & \multirow{2}{*}{$<0.001$} \\
\hline & Yes & 13 & $19.4 \%$ & 2 & $0.6 \%$ & 15 & $3.8 \%$ & \\
\hline & Total & 67 & $100.0 \%$ & 333 & $100.0 \%$ & 400 & $100.0 \%$ & \\
\hline
\end{tabular}


There were statistically significant difference between OSA $<126$ and 126 or more according to maternal complications, overall complications and complication types (Table 3).

Table (3): Comparison between OSA $<126$ and 126 or more according to maternal complications, overall complications and complication type.

\begin{tabular}{|c|c|c|c|c|c|c|c|c|}
\hline \multirow{2}{*}{\multicolumn{2}{|c|}{$\mathrm{P}_{\text {Parameters }}^{\text {Angle Group }}$}} & \multicolumn{2}{|c|}{$<126$} & \multicolumn{2}{|c|}{126 or more } & \multicolumn{2}{|c|}{ Total } & \multirow{3}{*}{$\begin{array}{l}\text { p-value } \\
<0.001\end{array}$} \\
\hline & & \multirow{2}{*}{$\begin{array}{c}\text { No. } \\
37\end{array}$} & \multirow{2}{*}{$\begin{array}{c}\% \\
55.2 \% \\
\end{array}$} & \multirow{2}{*}{$\begin{array}{l}\text { No. } \\
317\end{array}$} & \multirow{2}{*}{$\begin{array}{c}\% \\
95.2 \%\end{array}$} & \multirow{2}{*}{$\begin{array}{l}\text { No. } \\
354\end{array}$} & \multirow{2}{*}{$\begin{array}{c}\% \\
88.5 \%\end{array}$} & \\
\hline Maternal & No & & & & & & & \\
\hline complications & Yes & 30 & $44.8 \%$ & 16 & $4.8 \%$ & 46 & $11.5 \%$ & \\
\hline Overall & No & 24 & $35.8 \%$ & 315 & $94.6 \%$ & 344 & $86.0 \%$ & \\
\hline complic & Yes & 43 & $64.2 \%$ & 18 & $5.4 \%$ & 56 & $14.0 \%$ & \\
\hline \multirow{3}{*}{$\begin{array}{c}\text { Complications } \\
\text { Type }\end{array}$} & $\begin{array}{c}\text { Cervical } \\
\text { tear }\end{array}$ & 2 & $6.7 \%$ & 1 & $6.3 \%$ & 3 & $6.5 \%$ & \multirow{3}{*}{0.874} \\
\hline & $\begin{array}{c}\text { Perineal } \\
\text { tear }\end{array}$ & 9 & $30.0 \%$ & 6 & $37.5 \%$ & 15 & $32.6 \%$ & \\
\hline & $\begin{array}{l}\text { Vaginal } \\
\text { tear }\end{array}$ & 19 & $63.3 \%$ & 9 & $56.2 \%$ & 28 & $60.9 \%$ & \\
\hline
\end{tabular}

Receiver operating characteristics (ROC) curve was used to define the best cut off value of occiput-spine angle which was $\leq 126$, with sensitivity of $93 \%$ specificity of $79 \%$ positive predictive value of $52 \%$, and negative predictive value of $98.6 \%$ with diagnostic accuracy of $92 \%$ (Table 4 \& Figures 1, 2).

Table (4): Diagnostic Performance of occiput-spine angle in Discrimination of CS \& NVD and overall complications

\begin{tabular}{|c|c|c|c|c|c|c|}
\hline & Cut-off & Sen. & Sp. & PPV & NPV & Accuracy \\
\hline CS \& NVD & $<\mathbf{1 2 6}$ & $82 \%$ & $64.6 \%$ & $45 \%$ & $96.2 \%$ & $78.4 \%$ \\
\hline $\begin{array}{c}\text { Overall } \\
\text { complications }\end{array}$ & $<\mathbf{1 2 6}$ & $93 \%$ & $79 \%$ & $52 \%$ & $98.6 \%$ & $92 \%$ \\
\hline
\end{tabular}




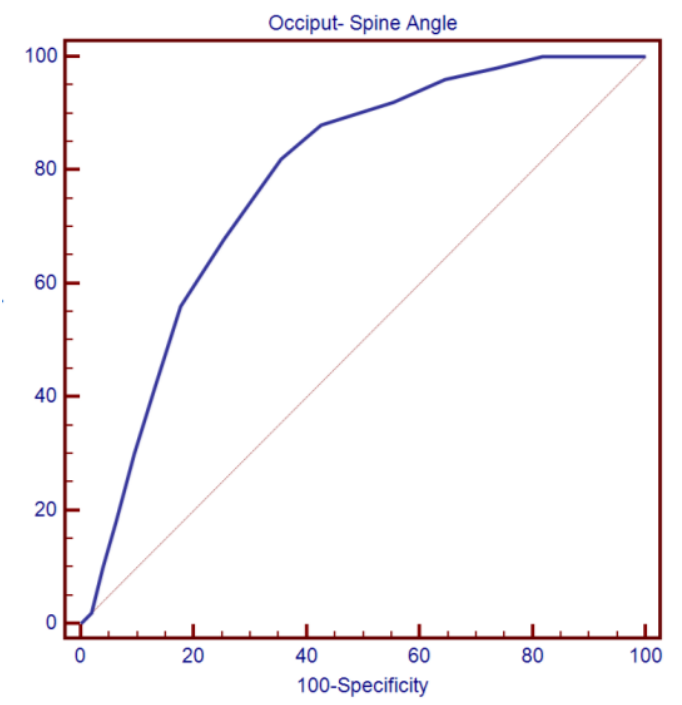

Figure (1): ROC curve "sensitivity and specificity" diagnostic Performance of occiput-spine angle in Discrimination of CS and NVD

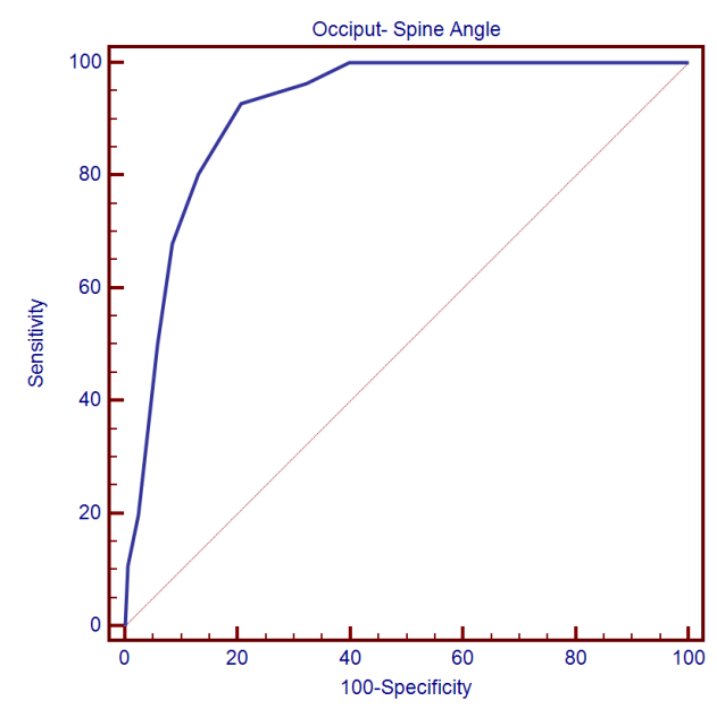

Figure (2): ROC curve "sensitivity and specificity" diagnostic Performance of occiput-spine angle in discrimination of overall complications

\section{DISCUSSION}

The diagnosis of the degree of deflexion is traditionally based on digital examination during labor, although the use of ultrasound to support clinical diagnosis has been reported (Ghi et al., 2012). The arrest of labor progression is the leading cause of obstetric interventions, including cesarean delivery and instrumental vaginal delivery (Cahill and Caughey, 2014).

The maternal risks of second-stage cesarean section include major hemorrhage, greater risk of bladder trauma, and extension tears of the uterine angle leading to broad ligament hematoma (Rane et al., 2010). Complications of obstructed labor for the baby include not getting enough oxygen which may result 
in death. It increases the risk of the mother getting an infection, having uterine rupture, or having post-partum bleeding (Neilson et al., 2010).

A parameter derived from ultrasound examination (the occiput-spine angle) has a relationship with the course and outcome of labor (Ghi et al., 2016).

The aims of this study were to quantify the degree of fetal head deflection via the use of ultrasound during the first stage of labor and to determine whether a parameter derived from ultrasound examination (the occiput-spine angle) has a relationship with the course and outcome of labor. 2D transabdominal ultrasound was done during the first stage of labor.

If fetal position was occipito-anterior and fetal presentation was vertex, twodimensional sagittal picture of the fetal head and upper spine was acquired and stored in the ultrasound machine. On this image, the offline measurement of the angle formed by a line tangential to the occipital bone and a line tangential to the first vertebral body of the cervical spine (occipito-spine angle) was performed to quantify the degree of fetal head flexion in respect to the trunk.

The sonographer was not involved in the patient's care and the managing obstetrician was blinded to the ultrasound findings and the occiput-spine angle. For each patient of the study group, the progress of labor using a partogram (cervical dilation, effacement, consistency, position and station) and the mode of delivery were assessed retrospectively.
We found with decrease occiput- spine angle, there was an increase in the rate of CS, abnormal progress of labor and increase both maternal and fetal complications. The cutoff value of Occiput- spine angle for safe vaginal delivery was 126 .

Regarding labor progress, we found abnormal progress in $77.6 \%$ when the OSA was less than 126 , while it was $11.6 \%$ when the angle was 126 or more which means that with decreasing the angle there is increase the probability of abnormal labor.

Regarding maternal complications, we found that incidence of complication $44.8 \%$ when the OSA was less than 126 while it was $4.8 \%$ when the angle was 126 or more which means that with decreasing the angle there is increase the probability of maternal complications.

The maternal complications are further specified in to cervical, vaginal and perineal tears which all increased with decrease the OSA angle with special concern to vaginal tear which was found in more than $60 \%$ with the angle group $<126$.

Regarding fetal complication, we found incidence of complication $19.4 \%$ when the angle was less than 126 and was $0.6 \%$ when the angle was 126 or more which means that with decreasing the angle there is increase the probability of fetal complications especially respiratory distress.

Regarding overall complications, we found its incidence $56.7 \%$ when the angle was less than 126 while it was $5.4 \%$ when the angle was 126 or more which means that with decreasing the angle there is 
increase the probability of overall complications.

Regarding mode of delivery, we found incidence of cesarean section $46.3 \%$ when the angle was less than 126 while it was $5.7 \%$ when the angle was 126 or more which means that with decreasing the angle there is increase the probability of Cesarean section.

Ghi et al. (2016) found that the mean value of the occiput-spine angle measured in the active phase of the first stage was $126 \pm 9.8$ (SD). The occiput-spine angle measurement showed a very good intraobserver, and a fair-to-good inter observer agreement. The occiput-spine angle was significantly narrower in women who underwent obstetric intervention (cesarean or vacuum delivery) due to labor arrest. A larger occiput-spine angle width (i.e., >125_) showed to be significantly associated with a shorter duration of labor.

There are a lot of studies preceding $G h i$ et al. (2016) trying to correlate between the degree of fetal head deflexion and rate of CS based on clinical finding not ultrasound findings but They were not proven to be clinically useful in predicting the occurrence of CS.

This study has a limitation regarding occipito-posterior presentation which was found in more than $25 \%$ of case during the first stage of labor.

\section{CONCLUSION}

The best OSA was 126 and below this angle there was an increase on the incidence of maternal and fetal complication with significant increase in rate of cesarean delivery. The occiputspine angle in the first stage of labor correlated significantly with the risk of obstructed labor Compared with spontaneous vaginal deliveries. Cases that required obstetric intervention demonstrated a smaller occiput-spine angle at a similar station, suggesting diminished flexion of the fetal head. For occiput anterior fetuses, the greater the degree of fetal head deflexion, the greater risk of operative delivery due to labor arrest.

Our data supported the obstetric notion that a deflexed fetal attitude may interfere with the fetal head descent because of an increase of the presenting diameter and a relative cephalo-pelvic disproportion, and this may ultimately increase the risk of arrested labor and obstetric intervention.

\section{REFERENCES}

\section{ACOG (American College of Obstetricians and Gynecologists) (2012): Induction of labor August 2012. American College of Obstetricians and Gynecologists. Int J Gynaecol Obstet., 114(2): 386-397.}

2. Cahill AG and Caughey AB (2014): Safe prevention of the primary cesarean delivery. Am J Obstet Gynecol., 210:179-93.

3. Cunningham FG, Leveno KJ and Bloom SL (2014): Abnormal labor. In: Cunningham FG, Williams JW, William's obstetrics. 24th ed. Pbl. New York, (NY): McGraw-Hill. Chapter 23. Pp. 455-472.

4. Ghi T. (2016): A new sonographic parameter to diagnose fetal head deflexion. Am J Obstet Gynecol., 2015: 84-89. 
5. Ghi T, Farina A, Pedrazzi A, Rizzo N, Pelusi G and Pilu G (2012): Diᄀagnosis of station and rotation of the fetal head in the second stage of labor with intrapartum translabial ultraרsound. Ultrasound Obstet Gynecol., 33: 331-6.

6. Kish K and Joseph VC (2013): Malpresentation and Cord Prolapse (Chapter 21). In Alan H. DeCherney. Current Obstetric \& Gynecologic Diagnosis \& Treatment. Lauren Nathan (Ninth ed.).Pbl. Lange/McGraw-Hill. 2013, Pp. 369.

7. Laughon SK, Branch DW, Beaver J and Zhang J. (2012): Changes in labor patterns over 50 years. Am J Obstet Gynecol., 206:1-9.

8. Madsen $K$, Gronbeck $L$ and Rifbjerg LC. (2013): Educational strategies in performing cesarean section. Acta Obstet Gynecol Scand., 92: 256-263

9. Neilson JP, Lavender T, Quenby S and Wray S. (2010): Obstructed labour. British Medical Bulletin, 67: 191-204.

10. Rane SM, Guirgis RR, Higgins B and Nicolaides KH. (2010): Models for the prediction of successful induction of labor based on preinduction sonographic measurement of cervical length. J Matern Fetal Neonatal Med., 17: 315-322.

11. Towner D, Castro MA, EbyWilkens E and Gilbert WM. (2010): Effect of mode of delivery in nulliparous women on neonatal intracranial injury. $\mathrm{N}$ Engl $\mathrm{J}$ Med., 341: 1709-1714. 


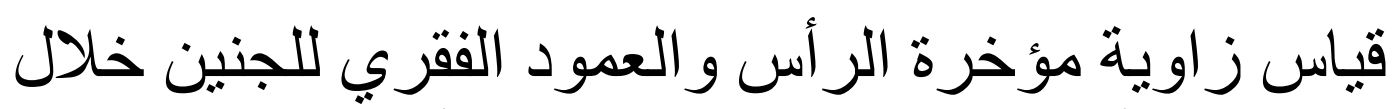

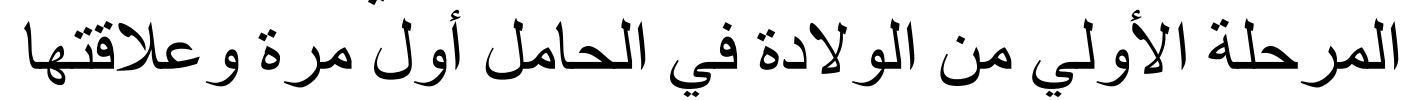
بطريقة اللو لادة الحامل

نور جمال عبد الناصر، إسماعيل محمد عبد العظيم ميرة، عبد المنصف عبد الحميا صديق

قسم النساء والتوليا ـ كلية الطب - جامعة الأزهر

E-mail: nourabdelnasser90@gmail.com

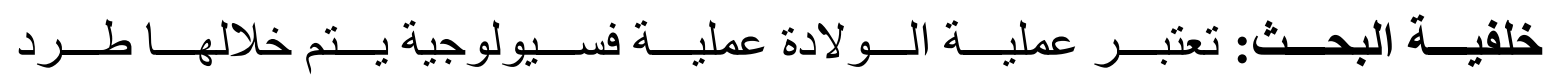

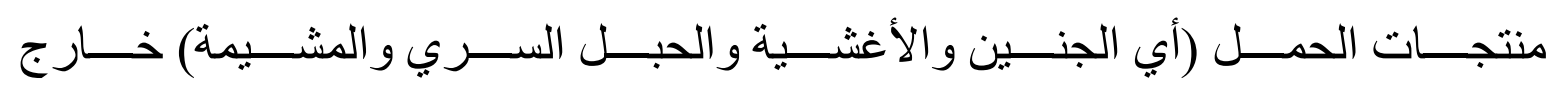

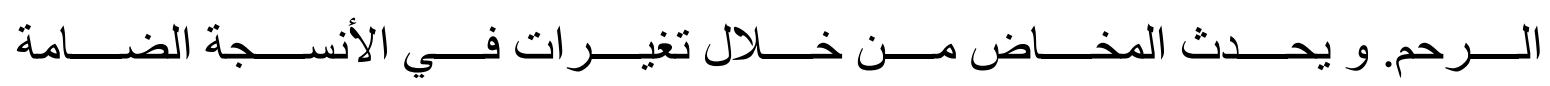

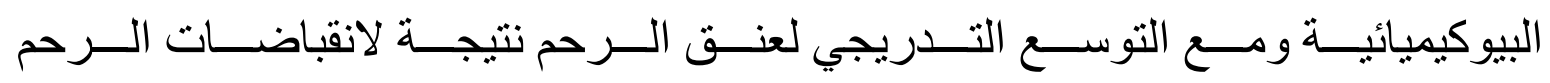
الإيقاعية المنز ايدة في التردد و الكثافة و المدة.

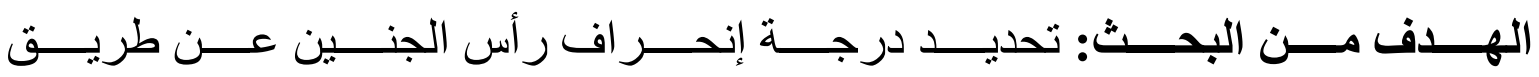

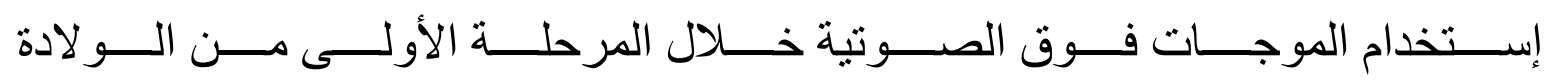

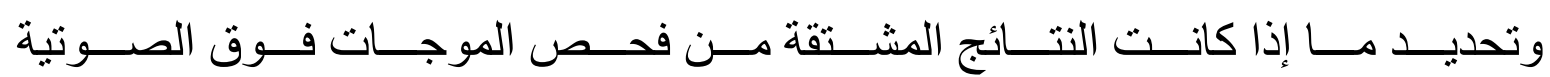

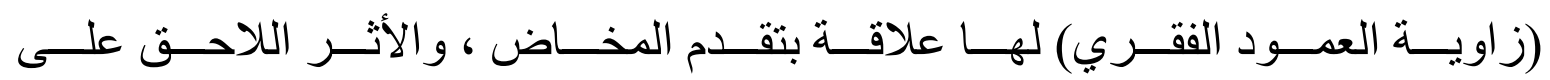
مضاعفات الأم و الجنين ومعدل الو لادة القيصرية.

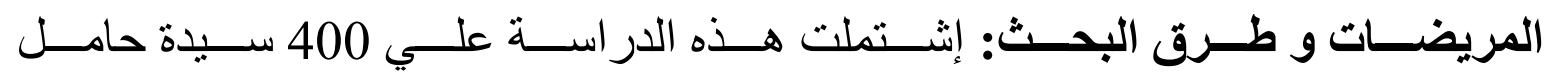

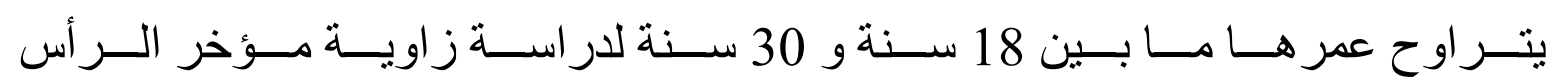

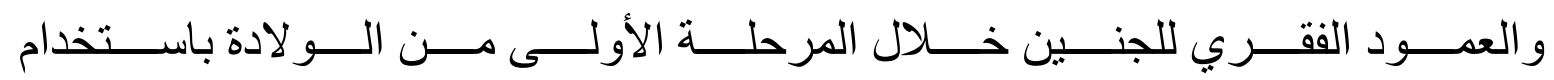

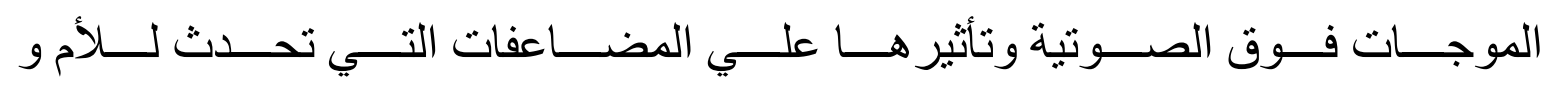
الطفل ومعدلات الو لادة القيصرية. 
MEASUREMENT OF FETAL OCCIPUT-SPINE ANGLE DURING THE... 2665

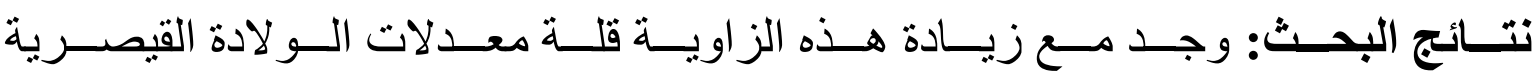

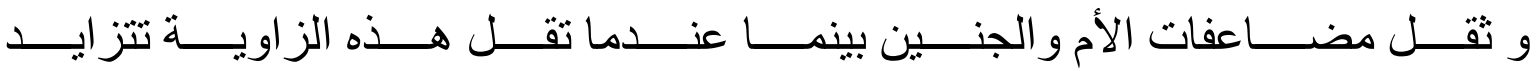

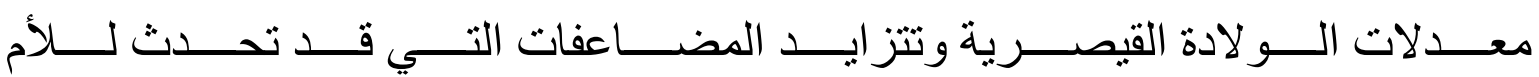

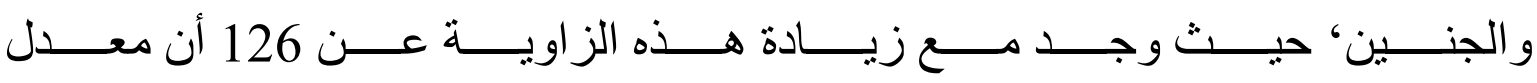

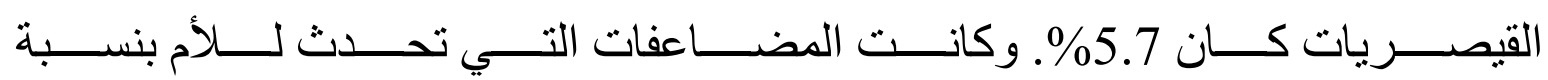

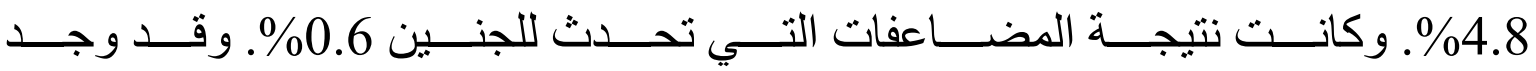

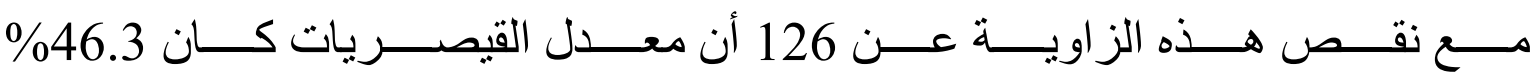

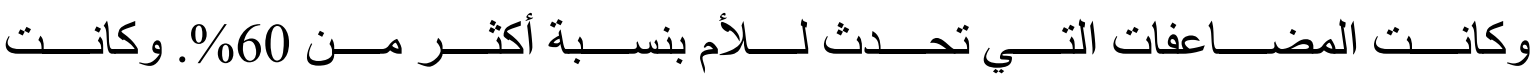
المضاعفات التي تحدث للجنين 19.4\%.

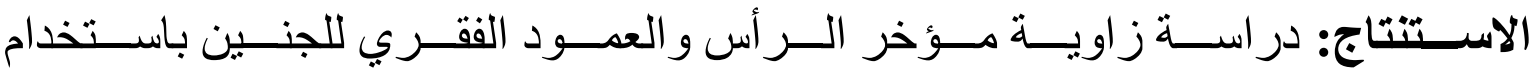

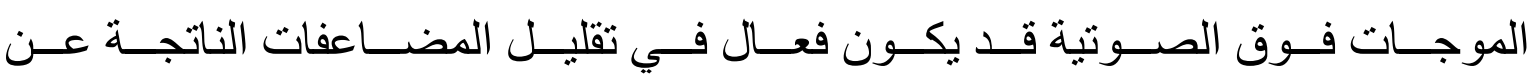
الو لادة.

الكلمـــات الدالـــة: زاويـــة مـــؤخر الــــر أس و العدـــود الفقــري للجنــين، المرحلـــة الأولى من الولادة الأولية. 